\title{
Correction to: Egypt's Diplomacy in War, Peace and Transition
}

\section{Correction to:}

\section{N. Fahmy, Egypt's Diplomacy in War, Peace and Transition, https://doi.org/10.1007/978-3-030-26388-1}

This book was inadvertently published without updating the following corrections and now updated as mentioned below.

Page 34, Paragraph 4, $2^{\text {nd }}$ sentence "After quick pleasantries, he looked at me and, to the astonishment of the Egyptian delegation, including myself, he said, "Ambassador, can’t Egypt take him out?"

Page 36, line 5, "This was a community of states that Egypt has best led by example, not by infringing on their sovereignty."

The updated online versions of these chapters can be found at https://doi.org/10.1007/978-3-030-26388-1_2 https://doi.org/10.1007/978-3-030-26388-1_6 https://doi.org/10.1007/978-3-030-26388-1_7 https://doi.org/10.1007/978-3-030-26388-1_8

(C) The Author(s) 2021 https://doi.org/10.1007/978-3-030-26388-1_11 
Page $129,2^{\text {nd }}$ paragraph, line 4 "During the October 1973 war, Libyans financed Egyptian weapons procurement and provided strategic depth including by allowing the use of its air bases as safe havens for Egyptian aircraft."

Page $157,2^{\text {nd }}$ paragraph, line 6 " $\mathrm{He}$ reiterated that he would regain his country's dignity and proper place in the global community, but not through or for the aim of a violent confrontation with the West, which would be detrimental to both."

Page $161,2^{\text {nd }}$ paragraph, line 4 "For the United States, accustomed to cheap energy, the 1973 Arab oil embargo came as a shock that shook the post-1967 American apathy toward Arabs."

Page $162,2^{\text {nd }}$ paragraph, line 1 "Ironically, while Arabs fought with Soviet weapons, the war became..."

Page $185,3^{\text {rd }}$ paragraph, line 3 "it had poisoned the relationship between the two Presidents."

Page 215, $2^{\text {nd }}$ paragraph, line 9 "At the same time, Mohamed El-Baradei, who was not a member of the WMC, and some others from different political constituencies suggested establishing a "transitional period" that would allow the political dust to settle before attempting to set the new political parameters for the country.” 